\title{
How do high school students elect their president of the school? ${ }^{1}$
}

\author{
Selvinaz Sacan $^{2}$
}

\begin{abstract}
This study has been carried out in order to determine the school assembly election attitudes of high school students. This descriptive study has been performed with 1380 students from 9th, 10th and 11th grades who attended center high schools of Aydin in 2014 - 2015 Academic Year. Demographic information form which was generated by researchers and five point likert scale was used in collection of data. PASW 18.0 packet software was used in the analysis of the data obtained from the study. It has been determined that $59 \%$ of students were girls, $41 \%$ were boys, 63\% were around 15-16 years old, 35\% were 17 and over it, 37\% from Vocational and Technical Anatolian high school, 24\% from Anatolian high school, 13\% from high school, 10\% from religious(Imam Hatip) high school, 6\% from science high school, 5\% from fine arts high school $4 \%$ from social sciences high school when the demographic features of students were assessed. When we look at their attitudes of school student president (or ASB president) elections; answers of students given for school student president (or ASB president) election loaded in to 4 factorial sub dimensions. And those are listed as follows: being a social person, having representative ability, importance of physical features and wanting to be school student president (or ASB president) qualities. $75 \%$ of students describes voting in school assembly elections as a responsibility, $53 \%$ of the students considers that elections are carried out in a fair and democratic manner, most of the youth have democratic values and minded participation rights. During the above mentioned candidateship period, it is criticized that candidates are committing financial supports, and there is no limit for those financial commitments.
\end{abstract}

Keywords: School assembly presidency, high school students, leader, democracy, participation,

\section{Introduction}

The main purpose of the education system is to enable people to grow up as the individuals who respect human rights, have a sense of responsibility, are hardworking, productive, can use the knowledge creatively, question it and reintroduce them to the society as active citizens with the aim of contributing to welfare and development of the society which they live in. Being an active citizen is possible with the fact that an individual uses his/her right to participation completely by being conscious of his/her rights and responsibilities. In this sense, it has become a priority at both national and international level to encourage specifically young people to participate in social and political life actively.

That the individuals participate in social and political life actively is also possible with democracy regime. In fact, democracy which is a good regime also accepted as the ideal politic part of $21^{\text {st }}$ century (Kincal, 2007). Implementation of the democracy is also possible with the fact

${ }^{1}$ This research is an extension of the report presented at the 1st International Congress on the Conduct of Women's Health and Education in Kocaeli on April 14-15, 2016.

${ }^{2}$ Assist. Prof., Adnan Menderes University, Faculty of Health Sciences, Department of Child Development, skuzucu@gmail.com 
that individuals gain behaviors that belong to democracy culture. One of the most important factors that determines the feature of being a democratic society is abundance of the educated individuals who have gained democracy consciousness (Mueller, 2009, Toktok, 2010). The most important element which provides social change and determines social structure is personal structures and behavior of the individuals living in that society. In this regard, there is a very close relation between democratic feature of the individuals from a country's behavior and democracy level existing in that country (Toktok, 2010).

It is important that the individuals and societies should learn democratic rules from either formal education or non-formal educational institutions, also with social life and especially it is so important that this behavior adaptation starts from childhood. In this sense, one of the primary duties of schools and education programs is to make children and young people gain democratic culture and democratic behavior (Davis, 2003; Blair, 2003; Tezcan, 2015). Akbari (2008) has stated 6 themes which need to be achieved in education for the year of 2010 and ensuing years. These are global thinking, having different skills and online skills, universal thinking skill for human rights and democracy, dealing with information overload and managing yourself.

Participation in childhood ages is fundamental for active participation in future (Bessell, 2009). It is very important to give children opportunity, responsibility and support in order to play an active role in participation in terms of the experience which they will gain (Stephenson, Gourley \& Miles, 2004; 11).

When this situation is examined abroad, it has been seen that citizenship education is given to the children of European Union (EU) countries and in this sense, a structure which aims to guide the students for active participation by improving; political literacy in them, their ability of critical thinking, some of their attitude and behavior on the topic. It has been stated that it is necessary to encourage students to participate in national and international projects, improve communication skills of them, experience democracy at school in order to enable students to participate in the society more with the aim of making them gain the expected behavior in providing active participation (Eurydice, 2005). In Swedish schools, school democracy works by organizing formal meetings just like class councils as a way for student participation and democratic education. According to the research, teachers usually associate school democracy and student participation with formal democratic meetings, and on a daily basis teachers' approach is mostly based on asking questions, expecting a proper or fundamentalist answer and analyzing this answer. So that teachers' focus is mostly on right answers instead of critical aspect; with that way the students are given very little opportunity to express their own opinions and comments or this opportunity is never given to them (Thornberg, 2010). In another study views and experiences of the children about democracy and their daily life at school, obstacles and limitations affecting school democracy have been discussed, it has also been confirmed that municipalities which are responsible for the schools have not taken any step to promote controversial democracy in their schools and unfortunately a common education and training which is controlled by the thought of open to discussion democracy is insufficient although teachers emphasize child rights, school rules and school democracy and the importance of student participation in teacher training programs in Sweden (Thonberg \& Elvstrand, 2012). In another empirical research on the effects of student participation on decision making process at school has been reviewed, it has been found some proof at medium level about the fact that participation of the students has positive effects on life skills, self esteem, social status, democratic skills and citizenship, student-adult relationships and school ethic. It has been found in the same research that student participation at school realizes in student councils, temporary school studying groups, intraclass decision making, intraschool decision making and multiple decision making environments, there is not enough research about their positive and negative effects on academic success of the students, activities, rules and health (Mager \& Nowak, 2012).

In the research which has been done about the effect of the democratic class environment on social skills of the students, it has been stated that democratic class environment 
has positive effects on the development of students' social skills (Ahmad, Said \&Jusoh, 2015). The fact that classroom environment is important for gaining democratic values also proved in an experimental study done with the $6^{\text {th }}$ Grade middle school students in Istanbul in our country. There were significant differences in terms of equality, clarity, being scientific, participation, working together and being respectful to others such as minorities found in the study in which activities about democratic values have been done in visual arts lesson and pre-test and post-test that have been applied (Konak, 2012). And also in Turkey, there have been some practices in order to encourage children and increase their participation level. One of these activities in schools within this will is to establish child clubs and the other one is to organize children councils. Children councils are giving opportunity to children to discuss and express their opinions about the issues that are neither affecting them or about them. In addition to that point, there are implementations such as children councils working under city councils, committees of child rights for providing them to participate in decision making processes and respecting their views in all areas (National Child Rights Strategy Paper and Action Plan, 2013-2017).

These implementations are new for our country and in this sense; there is an essential need for studies and projects. "Democracy Education and School Councils" project has been started with the aim of spreading democratic culture and respect to every segment of the society and providing consciousness of democracy including understanding of participation and tolerance, adopting culture of electing and being elected in the students who are in primary or secondary education, dealing with their problems with their own aspects with the protocol signed on 13 January 2004 between Presidency of the Grand National Assembly of Turkey and Ministry of National Education for meeting these requirements. Within the scope of the project, Province Student Council is created from presidents of student councils in every province and presidents of student councils elected in every province by Province Student Councils in order to create Student Council of Turkey. Student Council of Turkey comes together every year at General Assembly Saloon of Turkish Grand National Assembly in week of April 23 National Sovereignty, Congress and Children's Day every year. Decisions which have been made by student councils are accepted as advisory (TBMM, 2015).

When the legislation about the student councils which are one of the most important elements of participation of the children to processes in the schools is examined, it has been seen that legislation focuses on elections and election processes. And this situation is assessed in the schools in Turkey in terms of child participation, it has been understood that student councils are insufficient in terms of both working principles and implementation (Tuzun \& Sar11s1k, 2015). However participation right of the child is emphasized in The United Nations Convention of the Children Rights which is an inseparable and incontrovertible part of domestic law is also supported by our country. Child participation is a right which includes taking students' views about planning of social activities, learning processes and determining school rules in the schools and more functional implementations are needed for use of these rights. While it is aimed to increase activities and implementations during plan period of adopting students to the democratic culture, internalizing their own culture, raising generations who adopted universal values and whose national moral values in primary education programs in Target 2.4 in Strategic Plan of Ministry of National Education which includes 2010-2014 years, performance indicators for this objective have not been included. It has been stated in the $4^{\text {th }}$ article of the Declaration of the 10th Student Council of Turkey which was assembled on April $26^{\text {th }} 2013$ in Eskisehir that students decided "to be grown up character-wise individuals who have self-confidence, are strong-willed, can express themselves in any environment and condition, internalized national and universal values in order to adopt democratic culture to every part of the society and make democratic consciousness fundamental by making Student Council of Turkey more active" and this issue reported to Ministry of National Education and also declared to society (ttkb.meb.gov.tr). However there are not any targets or objectives for this issue in Strategic Plan including the years of 2015-2019 (meb.gov.tr.). 
As can also be seen from the information and sources provided and detections that have been made over current situation that participation confronts as one of the most important issues of an actual democratic life. The fact that viewpoint of the children taken into account as a natural part of life young ages effects participation of the individuals in their adulthood significantly. For this reason, implementations for encouragement of participation in schools need to be taken into account seriously. In order to create these important applications scientists, governmental organizations have a great responsibility. However it may seem that our country's scientific literature is pretty limited and poor over this important topic. In addition to this, it has been understood in accordance with the interviews done with the students and observations made in schools that presidential candidates of school council usually gives promises that are usually financial and tangible promises (such as buying original basketball for school, distributing water to all students and etc.) during their candidate speeches-campaign speeches and most of the children who are going to vote are supporting those candidates who are offering financial promises. In this situation, there is an inappropriate application for participation and the main principles of equality due to the fact that socio-economic situation of every student is different. In fact, it has been confirmed in the study which has been done with high school students who attend in school councils that students have reached the goals which they needed to reach and they also have gained skills with school councils. But it has been stated that there are important disruptions in elections for classroom and school representatives. Even if it the number is limited there were still some students who made negative comments such as "Presents and promotions have been distributed", this has showed that there are some deficiencies in supervision activities during election stages in the schools, it has also been stated that rules and recommendations about Formation of School Student Council and its studies which have been stated in Project Instructions of School Student Council of Ministry of National Education for election rules in stages of classroom representative are not usually followed (Celiktas, 2009). In the study which has been done with the target of determining which values holds various ethnic groups together living in our country and how much these values match up with course curriculum of Citizenship and Democracy Education Class given in $8^{\text {th }}$ grade, it has been confirmed that individuals who participate in the research are insufficient in especially recognizing cultural differences and introducing them which course book and program include values and judgements partially and it has been stated that the issue which individuals coming from different ethnics and cultures in research group complaint about mostly is prejudgement (Yigit, 2014). In another research in which democracy perception of the teachers is compared, it has been stated that attainments of democracy education in curriculum in secondary schools in Turkey are considered to be insufficient by teachers, attainments of democracy education in secondary schools in Austria are considered to be sufficient by teachers in Austria and it has been confirmed that teachers of both countries agree on "freedom of expression" (Ekici, 2013).

High school is a period in which children are capable of abstract thinking from concrete thinking in cognitive sense, they can understand events and concepts better and they have a broader perspective for life. It has been reported in the studies that political learning makes progress from simple to complex, level of knowledge and adoption increases in terms of general political structure, political choice and political authority with the age. And it has been confirmed by the research that learning level of the political principles and elements improves at the ages of 11-12 in general level and following current political events improves at the age of 13 and at later ages (Yesilorman, 2010).

This research, "Examining Attitudes of High school Students about Electing Criteria of President of School Council", has been done in order to both make high school period last period in which citizenship consciousness and democratic values are gained in formal education environment and determining deficiencies and requirements in such an important implementation and creating solution offers in our day which the issue of the fact that right to stand for election is decided to be 18 years old is discussed. 


\section{Purpose}

This study has been conducted for a better determination over the attitudes of the students about the election of school student president (ASB President in other words.). In addition to that, it is aimed to determine whether attitudes of the students about this election change according to gender, age, classroom level, school type, educational level of the parents and family income or not.

\section{Method and material}

\subsection{The place and time of the study}

This descriptive study was carried out with 9th, 10th, 11th grade high school students who were studying at high schools in the academic year of 2014-2015 in Aydin.

\subsection{Population and sample selection}

The target population of the research is all of the $9^{\text {th }}, 10^{\text {th }}, 11^{\text {th }}$ grade students who were studying at high schools in Aydin and participants are all students who filled data collection tools completely and were volunteers for the study without using any sampling method, data of 1380 students who filled the form completely has been assessed. 14.100 students including $12^{\text {th }}$ grade students were studying at 14 different high schools in academic year of 2014-2015 in Aydin.

\subsection{Data Collection}

The data was collected by distributing questionnaire forms to the students and making students fill the forms in classroom environment by the researcher. This process lasted 15-20 minutes in each classroom. The data of research was collected between March $23^{\text {rd }}-$ May $29^{\text {th }}$ 2015. Before the study, some instructions such as the aim of the study, the time which has been given to fill the form, the fact that participating the study is based on voluntariness, that they can end their participation at anytime, that information which they give was not used except the study and writing names in the questionnaires was not necessary were given to the students. And if they had any question, questions were answered and oral consents about participating the study were taken.Written permission about a essay which contains the objective and scope of the study was received from the relevant institution.(The Letter of approval numbered 2959996 and dated 18.03.2015 of AydinProvincial Directorate of National Education)

\subsection{Data Collection Tools}

Demographic information form created by the researchers and attitude survey of election of president of the school which includes 5 point likert scale have been used in data collection. Demographic information form has included questions about the age, gender, classroom level, school type, type of the family, education and profession situation of parents, level of monthly income, situation of arranging social activities at school, students' area of interests such as art and sport, teams and organizations which they join, the time which they spare for media tools, mother-father, sibling, friend relationships, school success, situation of having problem with the school, whether they have daily responsibilities except school, situation of doing voluntary work.

Questions of attitude survey of election of president of the school have been created by taking into account criteria which students share one another and pay attention during election of president of the school with the related literature review. After creating survey questions, opinions of 3 domain experts have been taken. Initially, survey questions have been including 35 entries but the number of them has become 28 after all assessments. Factor analysis has been made by assessing answers of the participants and 86 entries have created 4 factorial subdimensions after factor analysis. These are;

That president of the school;

1. Is sociable,

2. Has ability of representation,

3. Physical characteristics of him are important,

4. Iswilling to be president of the school. 
Table 1. Factor Analysis

\begin{tabular}{|c|c|c|c|c|}
\hline & Com & ents & & \\
\hline & 1 & 2 & 3 & 4 \\
\hline President of the school must be a social person. &, 745 & & & \\
\hline President of the school must be a social person. &, 676 & & & \\
\hline President of the school must be a social person. &, 667 & & & \\
\hline President of the school must be a social person. &, 625 & & & \\
\hline President of the school must be a social person. &, 510 & & & \\
\hline President of the school must be a social person. &, 492 & & & \\
\hline President of the school must be a social person. &,- 379 & & & \\
\hline President of the school must be a social person. &, 347 & & & \\
\hline $\begin{array}{l}\text { President of the school must have the ability to } \\
\text { represent the students. }\end{array}$ & &, 667 & & \\
\hline $\begin{array}{l}\text { President of the school must have the ability to } \\
\text { represent the students. }\end{array}$ & &,- 606 & & \\
\hline $\begin{array}{l}\text { President of the school must have the ability to } \\
\text { represent the students. }\end{array}$ & &, 564 & & \\
\hline $\begin{array}{l}\text { President of the school must have the ability to } \\
\text { represent the students. }\end{array}$ & &,- 506 & & \\
\hline $\begin{array}{l}\text { President of the school must have the ability to } \\
\text { represent the students. }\end{array}$ & &, 501 & & \\
\hline $\begin{array}{l}\text { President of the school must have the ability to } \\
\text { represent the students. }\end{array}$ & & , 482 & & \\
\hline $\begin{array}{l}\text { President of the school must have the ability to } \\
\text { represent the students. }\end{array}$ & &, 479 & & \\
\hline $\begin{array}{l}\text { President of the school must have the ability to } \\
\text { represent the students. }\end{array}$ & &, 505 & & \\
\hline $\begin{array}{l}\text { President of the school must have the ability to } \\
\text { represent the students. }\end{array}$ & &, 393 & & \\
\hline $\begin{array}{l}\text { President of the school must have the ability to } \\
\text { represent the students. }\end{array}$ & & ,376 & & \\
\hline $\begin{array}{l}\text { President of the school must have the ability to } \\
\text { represent the students. }\end{array}$ & &, 320 & & \\
\hline $\begin{array}{l}\text { Physical characteristics of president of the school are } \\
\text { important. }\end{array}$ & & & & \\
\hline $\begin{array}{l}\text { Physical characteristics of president of the school are } \\
\text { important. }\end{array}$ & & & ,613 & \\
\hline $\begin{array}{l}\text { Physical characteristics of president of the school are } \\
\text { important. }\end{array}$ & & &, 543 & \\
\hline $\begin{array}{l}\text { Physical characteristics of president of the school are } \\
\text { important. }\end{array}$ & & &, 502 & \\
\hline $\begin{array}{l}\text { Physical characteristics of president of the school are } \\
\text { important. }\end{array}$ & & &, 440 & \\
\hline $\begin{array}{l}\text { Physical characteristics of president of the school are } \\
\text { important. }\end{array}$ & & & ,408 & \\
\hline I don't want to be president of the school. & & & &,- 750 \\
\hline I don't want to be president of the school. & & & & 681 \\
\hline I don't want to be president of the school. & & & & ,333 \\
\hline
\end{tabular}




\subsection{Data Analysis}

Descriptive statistics, reliability analysis, factor analysis, KolmogorovSmirnov, Man Whitney U, Kruskal Wallis and Jonckheere-Terpstra Test, Anova and t-test analysis have been used in the scope of the analysis. PASW 18.0 package sofware has been used in the analysis of data obtained in the research. 1380 individuals have participated in the research. Rate of 0,928 has been obtained as Cronbach's Alpha after the research. Reliability and validity of likert scale questionnaire used in the research after this rate have been provided. Significance level of 0.05 has been taken into consideration in differences and relations among variables. Questions used in the questionnaire have been moved forward by dividing into factors and sub-dimensions.

\section{Results}

Information about socio-demographic characteristics of high school students has been presented at Table 2.

Table 2. Range of socio-demographic characteristics of high school students

\begin{tabular}{|c|c|c|c|c|c|}
\hline Characteristics & $\mathbf{n}$ & $\%$ & Characteristics & $\mathbf{n}$ & $\%$ \\
\hline Gender & & & Age & & \\
\hline Female & 809 & 59 & $13-14$ & 26 & 2 \\
\hline Male & 571 & 41 & $15-16$ & 869 & 63 \\
\hline & & & $17+$ & 485 & 35 \\
\hline Classroom level & & & Family type & & \\
\hline $9^{\text {th }}$ & 450 & 33 & Nuclear family & 1142 & 83 \\
\hline $10^{\text {th }}$ & 457 & 33 & Extended family & 154 & 11 \\
\hline $11^{\text {th }}$ & 467 & 34 & Broken family & 82 & 6 \\
\hline School type & & & $\begin{array}{l}\text { Situation of family } \\
\text { income }\end{array}$ & & \\
\hline Science high school & 82 & 6 & 950 TL and less & 203 & 15 \\
\hline Anatolian high school & 329 & 24 & 951-1500 TL & 420 & 30 \\
\hline Voc. Tec. And. L. & 504 & 37 & $1501-2500 \mathrm{TL}$ & 323 & 23 \\
\hline High School & 186 & 13 & 2501 TL and more & 432 & 31 \\
\hline Social Sciences & 62 & 4 & & & \\
\hline Religious & & & & & \\
\hline Vocational & 143 & 10 & & & \\
\hline Fine Arts & 73 & 5 & & & \\
\hline $\begin{array}{l}\text { Occupation } \\
\text { mother }\end{array}$ & & & Occupation of father & & \\
\hline Housewife & 945 & 69 & Not working & 40 & 3 \\
\hline Employee & 69 & 6 & Employee & 260 & 19 \\
\hline Officer & 204 & 15 & Officer & 350 & 26 \\
\hline Self-employment & 43 & 3 & Self-employment & 347 & 25 \\
\hline Other & 111 & 8 & Other & 375 & 27 \\
\hline $\begin{array}{l}\text { Educational } \\
\text { background } \\
\text { mother }\end{array}$ & & & $\begin{array}{l}\text { Educational } \\
\text { background of father } \\
\text { Illiterate }\end{array}$ & & \\
\hline Illiterate & 55 & 4 & Literate & 17 & 1 \\
\hline Literate & 23 & 2 & Primary school & 21 & 2 \\
\hline Primary school & 458 & 33 & Secondary school & 348 & 25 \\
\hline Secondary school & 262 & 19 & High school & 272 & 20 \\
\hline High school & 317 & 23 & University and more & 292 & 21 \\
\hline University and more & 259 & 19 & & 419 & 30 \\
\hline $\begin{array}{l}\text { Area of sportive } \\
\text { interest }\end{array}$ & & & $\begin{array}{l}\text { Area of interest in art } \\
\text { Yes }\end{array}$ & & \\
\hline Yes & 1043 & 76 & No & 883 & 64 \\
\hline No & 337 & 24 & & 497 & 36 \\
\hline
\end{tabular}


Sacan, S. (2017). How do high school students elect their president of the school? Journal of Human Sciences, 14(2), 13381355. doi: $10.14687 /$ jhs.v14i2.4543

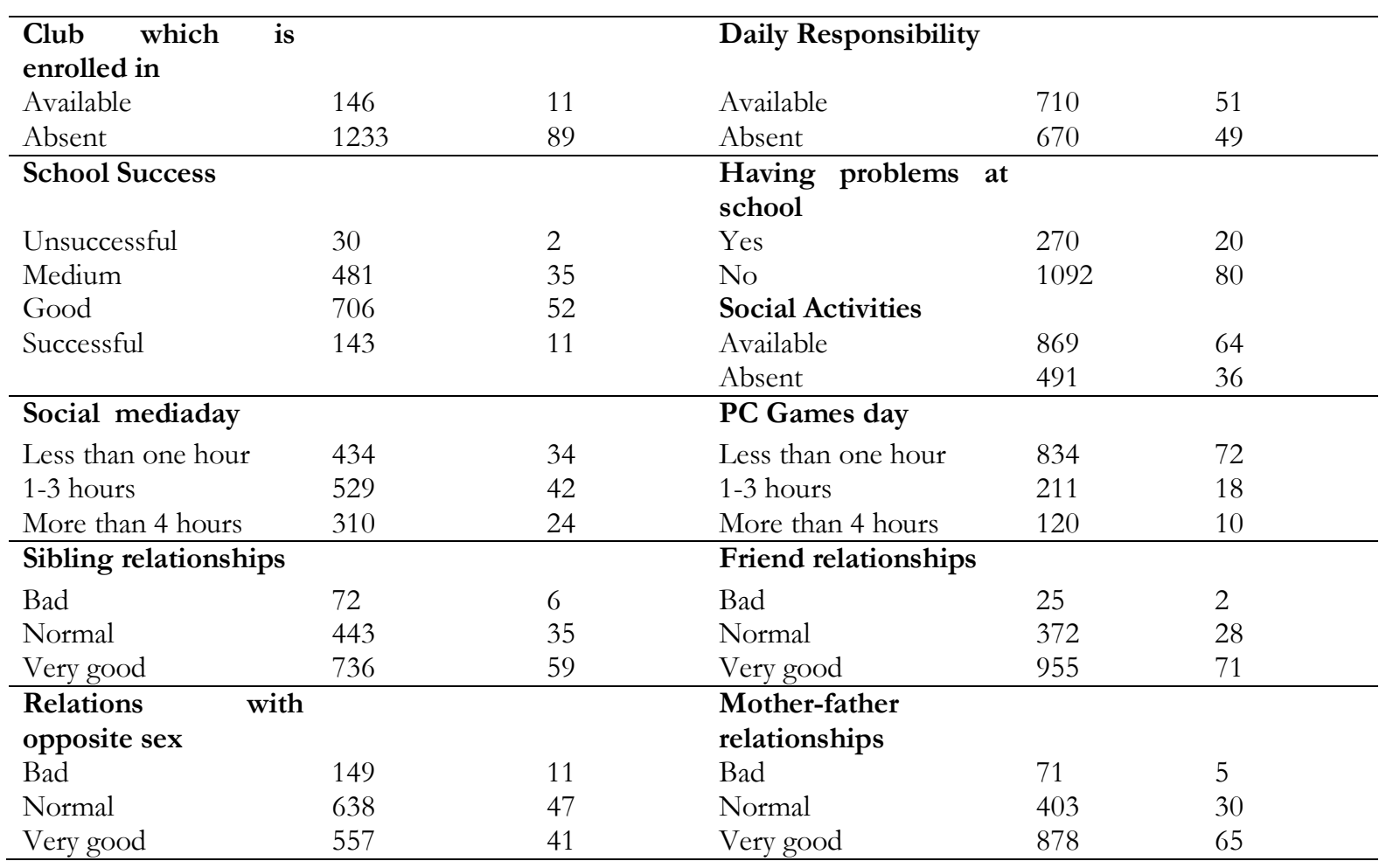

$59 \%$ of the students who have participated in the research are women, $41 \%$ of them are men and 63\% of them are 15-16 years old. 37\% of them are still attending vocational high school, 24\% of them are attending Anatolian high school. 54\% of the students have spent most of their lives in country town and $83 \%$ of them have elementary families. Mothers of most students are housewives ( $\% 69)$, fathers of $26 \%$ of them are officers, fathers of $25 \%$ of them are self-employed persons. Educational background of mothers of $33 \%$ of them is primary school, $42 \%$ of them graduated from high school and university, educational background of fathers of $25 \%$ of them is primary school and $51 \%$ of them graduated from high school and university. While level of family income of $31 \%$ of students is $2501 \mathrm{TL}$ and more, $30 \%$ of them have income between 951-1500 TL. 52\% of the students have assessed their school success as good. $76 \%$ of the students have sportive interest areas, $64 \%$ of them are interested in art. $89 \%$ of them are not a member of any institution, organization or club. While $51 \%$ of them have some extra daily responsibilities except the school, $49 \%$ of them do not have any responsibility. Most of the students have stated that they have good relationships with their siblings, friends, parents and the opposite sex. $80 \%$ of the students have stated that they don't have any problem with the school and most of them $(\% 64)$ have stated that social activities are arranged at their schools. It has been stated that students spend 1-3 hours in social media ( $\% 42)$, less than one hour for computer games (\%72), 1-3 hours watching television (\%42) and more than 4 hours listening to music $(\% 37)$. 
Table 3.Comparasion of attitude factors while electing president of the school according to socio-demographic characteristics of the students

\begin{tabular}{|c|c|c|c|c|c|c|c|c|c|c|c|c|}
\hline \multirow{3}{*}{$\begin{array}{l}\text { Variables } \\
\text { Gender }\end{array}$} & \multicolumn{3}{|c|}{$\begin{array}{l}\text { President of the school } \\
\text { must be a social person. }\end{array}$} & \multicolumn{3}{|c|}{$\begin{array}{l}\text { President of the school must } \\
\text { have the ability to represent } \\
\text { the students. }\end{array}$} & \multicolumn{3}{|c|}{$\begin{array}{l}\text { Physical characteristics of } \\
\text { president of the school are } \\
\text { important. }\end{array}$} & \multicolumn{3}{|c|}{$\begin{array}{l}\text { I don't want to be president } \\
\text { of the school. }\end{array}$} \\
\hline & Man Whitney U & SD & $\mathbf{P}$ & Man Whitney U & SD & $\mathbf{P}$ & Man Whitney U & SD & $\mathbf{P}$ & Man Whitney U & SD & $\mathbf{P}$ \\
\hline & 1,453 & & 0,000 & 1,579 & & 0,045 & 1,501 & & 0,001 & 1,489 & & 0,000 \\
\hline Age & Kruskal Wallis & SD & $\mathbf{P}$ & Kruskal Wallis & SD & $\mathbf{P}$ & Kruskal Wallis & SD & $\mathbf{P}$ & Kruskal Wallis & SD & $\mathbf{P}$ \\
\hline \multirow{2}{*}{ School Type } & Anova & SD & $\mathbf{P}$ & Anova & SD & $\mathbf{P}$ & Anova & SD & $\mathbf{P}$ & Anova & SD & $\mathbf{P}$ \\
\hline & 5,007 & 6 & 0 & 10,487 & 6 & 0 & 3,442 & 6 & 0,002 & 3,830 & 6 & 0,001 \\
\hline \multirow{2}{*}{ Classroom Level } & Jonckheere-Terpstra & SD & $\mathbf{P}$ & Jonckheere-Terpstra & SD & $\mathbf{P}$ & Jonckheere-Terpstra & SD & $\mathbf{P}$ & Jonckheere-Terpstra & SD & $\mathbf{P}$ \\
\hline & $-2,075$ & 4 & 0,038 & 3,843 & 4 & 0 & $-2,176$ & 4 & 0,03 & 1,427 & 4 & 0,154 \\
\hline \multirow{2}{*}{$\begin{array}{l}\text { Educational } \\
\text { background } \\
\text { mother }\end{array}$} & Jonckheere-Terpstra & SD & $\mathbf{P}$ & Jonckheere-Terpstra & SD & $\mathbf{P}$ & Jonckheere-Terpstra & SD & $\mathbf{P}$ & Jonckheere-Terpstra & SD & $\mathbf{P}$ \\
\hline & 2,013 & 7 & 0,044 & 1,507 & 7 & 0,132 & $-1,124$ & 7 & 0,261 & 1,866 & 7 & 0,026 \\
\hline $\begin{array}{l}\text { Educational } \\
\text { background } \\
\text { father }\end{array}$ & 1,954 & 7 & 0,051 & 2,317 & 7 & 0,021 & $-1,295$ & 7 & 0,195 & 1,881 & 7 & 0,06 \\
\hline \multirow{2}{*}{$\begin{array}{l}\text { Average monthly } \\
\text { income }\end{array}$} & Anova & SD & $\mathbf{P}$ & Anova & SD & $\mathbf{P}$ & Anova & SD & $\mathbf{P}$ & Anova & SD & $\mathbf{P}$ \\
\hline & 1,732 & 4 & 0,141 & 2,534 & 4 & 0,039 & 0,565 & 4 & 0,688 & 3,407 & 4 & 0,09 \\
\hline \multirow[t]{2}{*}{ Family type } & KolmogorovSmirnov & SD & $\mathbf{P}$ & KolmogorovSmirnov & SD & $\mathbf{P}$ & \begin{tabular}{|l|}
$\begin{array}{l}\text { Kolmogorov } \\
\text { Smirnov }\end{array}$ \\
\end{tabular} & SD & $\mathbf{P}$ & KolmogorovSmirnov & SD & $\mathbf{P}$ \\
\hline & 1,589 & & 0,013 & 0,826 & & 0,502 & 0,569 & & 0,903 & 1,072 & & 0,201 \\
\hline
\end{tabular}


School presidential election attitudes do not differ according to gender, age, school type, class level, mother education, father education, monthly average income level and family type ( $\mathrm{p}>$ 0,05). However, when attitude sub-dimensions factors of election of president of the school are examined, Sig values have been found less than 0,05 in its 4 factors. The factor of the fact that president of the school must be a social person changes according to the gender (males), age (1517 years old), school type (Anatolian high school), classroom level ( ${ }^{\text {th }}$ grade), educational background of mother (primary school) and family type (elementary school). The factor of the fact that president of the school must have the ability of representation changes according to gender (females), school type (Anatolian high school), educational background of father (primary school), monthly income level ( 2501 TL and more). The factor of the fact that physical characteristics of president of the school are important changes according to the gender (females), school type (Vocational and Technical Anatolian High school) and classroom level $\left(10^{\text {th }}\right.$ grade).The factor of the fact that I don't want to be president of the school changes according to the gender (males), school type (high school), educational background of mother (secondary school). In other words; When it is examined in terms of the gender variable;

- The factor of the fact that president of the school must be a social person changes according to the gender. The biggest average belongs to the men.

- The factor of the fact that president of the school must have the ability to represent the students changes according to the gender. The biggest average belongs to the women.

- The factor of the fact that physical characteristics of president of the school are important changes according to the gender. The biggest average belongs to the women.

- The factor of the fact that I don't want to be president of the school changes according to the gender. The biggest average belongs to the men.

When it is examined in terms of the age variable;

- Only the factor of the fact that president of the school must be a social person changes according to the age. The biggest average belongs to the 15-16 age group.

When it is examined in terms of the school type variable;

- The factor of the fact that president of the school must be a social person changes according to the school type. The biggest average belongs to group of the Anatolian High School.

- The factor of the fact that president of the school must have the ability to represent the students changes according to the school type. The biggest average belongs to group of the Anatolian High school.

- The factor of the fact that physical characteristics of president of the school are important changes according to the school type. The biggest average belongs to group of the Vocational and Technical Anatolian High school.

- The factor of the fact that I don't want to be president of the school changes according to the school type. The biggest average belongs to the high school group.

When it is examined in terms of the classroom level variable;

- The factor of the fact that president of the school must be a social person changes according to the classroom level. The biggest average belongs to group of the $9^{\text {th }}$ grade.

- The factor of the fact that president of the school must have the ability to represent the students changes according to the classroom level. The biggest average belongs to group of the $10^{\text {th }}$ grade.

- The factor of the fact that physical characteristics of president of the school are important changes according to the classroom level. The biggest average belongs to group of the $10^{\text {th }}$ grade.

- The factor of the fact that I don't want to be president of the school doesn't change according to the classroom level. 
When it is examined in terms of variable of educational background of the mother;

- The factor of the fact that president of the school must be a social person changes according to the educational background of the mother. The biggest average belongs to the primary school group.

- The factor of the fact that I don't want to be president of the school changes according to the educational background of the mother. The biggest average belongs to the secondary school group.

When it is examined in terms of variable of educational background of the father;

- The factor of the fact that president of the school must have the ability to represent the students changes according to the educational background of the father. The biggest average belongs to the primary school group.

When it is examined in terms of variable of the monthly income level of the family;

- Only the factor of the fact that president of the school must have the ability to represent the students changes according to the monthly family income. The biggest average belongs to the $2501+$ group.

When it is examined in terms of the family type variable;

- Only the factor of the fact that president of the school must be a social person changes according to the family type. The biggest average belongs to the nuclear family group.

\section{Discussion}

Significant differences have been confirmed in the terms of candidates' social abilities, physical appearance, willingness and ability to represent. These evidences show parallelism with development features of the individuals who are the participants of the research. In addition to this, that $75 \%$ of the students think that voting in the elections of president of the school is a responsibility and $53 \%$ of them think that elections are organized in a democratic environment have been interpreted as most of the young people experience democratic values and pay attention to their participation rights. The issues of the fact that candidates give tangible and financial promises to the students in candidacy process and these promises are not limited. This has been criticized. Before questionnaire forms have been filled in the scope of the research, a substantial part of the students of Vocational and Technical Anatolian High school have expressed that they don't know anything about neither their school representative president nor the election system. They also expressed that they never participated in them before either. While course of "Citizenship and Democracy Education" was an elective course for $8^{\text {th }}$ grade students in academic year of 2010-2011 in our country, it was a compulsory course in 2011-2012 academic year (Akgun, 2013).

It is a thought-provoking situation that students of Vocational and Technical Anatolian High schools who take many courses in the issue of democracy and citizenship education until high school period still do not have any idea about the election of president of the school and don't vote in the elections. Although this subject is discussed in both introduction to science class in primary school and social studies class in secondary school as a unit and in the course of citizenship and democracy education, efficiency of the courses has been criticized. In the comparative study done for the way of teaching the issue of election of class president in course books of introduction to science which have been taught in Germany and Turkey of $3^{\text {rd }}$ grade students, it has been reported that while being candidate for class presidency and participation process to school council with democratic election take part in an encouraging way in course books tea taught in Germany, the issue is at comprehension level and it includes election of grounded class presidency in course books taught in Turkey (Pamuk \& Pamuk, 2016). And in another study done with $8^{\text {th }}$ grade students in secondary school who took course of citizenship and democracy education in academic year of 2014-2015, it has been confirmed that course subjects are taught theoretically, but information which has been taught is not practised in daily life (Akdu, 2016). In addition to this, it is seen that this group usually starts working by dropping 
out the school after high school when statistical data about the students of vocational and technical Anatolian high school has been examined. It has been assessed that it is highly important that students of vocational and technical Anatolian high school gain awareness of democratic life at least in high school years. It has been stated that according to research findings, male students, 15-16 years old students and students attending Anatolian high school pay attention to the fact that president of the school is a social person. Man, who is a social being is both effected by environment in which he lives and affects it, too. Being social is a feature that increases peer acceptance of teenager with the features of being loved, preferred. Being accepted by peer group promotes self-confidence of teenager and enables him to be effective in peer group (Kulaksizoglu, 2006; 88). Being social means also having social skill in a way. Social skill includes behaviour in 3 categories as interpersonal behavior (such as collaborating, speaking, playing game and etc), personal behaviour (such as expressing his feelings, self-concept, moral conduct, conscience) and behavior relating to the duty (such as having responsibility, obeying the rules) (Cifci \& Sucuoglu, 2009; 20 quoted from Merrell and Gimpel, 1998).

Leadership arises as an interaction process in a group. Some characteristics such as being energetic, patient, reliable and having social skills increase efficiency of the leaders (Korkmaz et al., 2015; 123-124). Being a nice and loved person is also one of the characteristics that increases the effect (Kag1tc1bas1, 2006; 186). Having the ability of representation has been found important for female students, $10^{\text {th }}$ grade students, students attending Anatolian high school and students whose average monthly family income is 2500 and more. Representation concept accepted as basic condition of the participation is very important for adopting democracy culture. Kant expresses that citizens can only protect their rights best with representative system and government can prevent use of power in an arbitrary way (Kurtbas, 2016 quoted from Köchler, 2000). Representation is a determination period of a representative who has been authorized by ruled people in order to make necessary decisions on their behalf when they can't realize their independence rights (Nacak, 2015). It has been stated that successful leaders have characteristics of credibility, reliability, motivating the group with his positive relationships, using group resources correctly (Hortacsu, 2007; 125 quoted from Chemers). In this sense, it is remarkable that students pay attention to personal characteristics of presidency candidate in elections of school council presidency. In addition to this, cultural characteristics also affect persuasion process of candidate of leadership. Social identities are emphasized and valuable in communitarian cultures like our country (Kag1tc1bas1, 2006; 360-361). Social identities are the individuals who are seen as leader by politicians, historians and the society (Liu \& Hilton, 2005). How much the position which is perceived by the individuals in society is high, the situation of the fact that individuals believe that person or group what is saying and also obeying it will be high (Kagitc1bas1, 2006; 81).

The importance which has been given to the friend increases in adolescence period and young individual pays attention to values and world views of their friends. Social acknowledgments of young people who have good relationships with their peers by the group are higher. School success, interests, abilities, physical characteristics, intelligence and emotional maturity of the young individual affect the level of being adopted and accepted in social environment. In a study done with $9^{\text {th }}, 10^{\text {th }}, 11^{\text {th }}$ grade students, students have identified the students who have social influence, collaborate, who are lovable, and popular as social individuals but also have aggressive characteristics as leaders (Subas1, 2009). And in another study, it has been stated that popular teenagers have prosocial behaviour, feature of dressing up smartly, physical attractiveness, athletic abilities besides aggressive characteristics (Dijkstra et al., 2015 quoted ).

In another study which examines friend relationships of $11^{\text {th }}$ grade students, it has been found that students pay attention most to the fact that their friends are confidant and reliable ( Buyuksahin Cevik \& Atıc1, 2008). In this sense, it has been stated that the most important values of the friendships in adolescence period are loyalty and faithfulness (Bee \& Boyd, 2009; 628). 
It has been stated that female students, $10^{\text {th }}$ grade students, students attending vocational and technical Anatolian high school pay attention to the physical characteristics of president of school council more. Physical characteristics become the main interest area for a young individual and his body becomes a symbol of his ego in adolescence period which starts with rapid physical change and development. Assessments of the family or environment such as ugly-beautiful for body of the individual in childhood period are effective in forming body image and young individual improves sensitiveness for his physical appearance in youth period by depending on these assessments (Koknel, 2011; 178-179). Young people are impressed by the model presented as ideal body sizes with the effect of social and cultural structure of the environment which they live in, peer group and media in adolescence period. Because being beautiful and attractive physically affects the importance given to the individual and determines his place in the society, being beautiful, looking beautiful and being liked become more important for female teenagers than males in the societies which pay attention to appearance. High schools which young people will attend are usually determined according to the points which they take in the transition to secondary education examination rather than their abilities and interests in our country.Young people who cannot attend any Anatolian high school in this system continues vocational high school. For this reason, young people attending vocational high schools usually are the students who do not have high academic objectives much and aims to begin working in a short time and interests of these young people are different, too.

In the studies conducted with adults about personal characteristics of the leaders, it has been stated that leaders are cleverer than other people, have good addressing ability, are tall and beautiful. In addition to this, it has been stated that leader is a person who responds the requirements for environment most and believes in himself and the group which he addresses, knows the requirements of the group and are sensitive for these requirements (Kagitc1bas1, 2006; 295-296). When we examine criteria of electing the leader of teenagers, it has been observed that they have attitudes like adults.

It has been found in research findings that teenagers going to general high school and male teenagers do not want to be president of school council. Young individuals reaching from concrete thinking to abstract thinking cognitively in adolescence period start thinking about the concepts such as death, philosophy, politics, religion more and show awareness of social problems more (Derman, 2008). In a study conducted with primary school students, it has been detected that politic socialisation levels of girls are higher than boys in terms of recognizing political authority and structure and political party preference of the girls is lower than boys' and there is a significant difference in adoption of general political values and elements (Yesilorman, 2010). Konak (2012) has stated that democratic attitude points of female students are higher than boys' although democratic attitudes of the students do not show any significant difference according to the gender. In the study done by Yildı-Baklavac1 (2015), it has been found that general attitudes of secondary school students for school student councils are high, general attitudes, democratic learning outcome, utility, taking role, prejudice attitudes based on gender for school student councils of female students are more positive than male students. In another study, it has been found that there is no difference between genders in the issue of political interest of the young people, girls are effected by participation situations of their parents and boys are affected by social and civil participation of their parents and sense of social and institutional trust is effective in political participation of young people (Cicognani et al., 2012). It has been stated in a national study done in Italy that political interests of female and male teenagers who are 14 years old are similar, gender differences start to occur at 18-19 years old and gender difference increases in adulthood period gradually (Cicognani et al., 2012 quoted from Istat). In other studies conducted in different societies, it has been reported that men are more interested in political issues than women, they participate in political life more actively and women participate in informal political activities as group participation rather than personal participation (Cicognani et al., 2012 quoted from Wilson ). 
Adolescence is also a critical period for socialisation of people and experiences of the individual in this period affect his behaviour in adulthood period directly. It is seen in lots of studies addressing political socialisation which is one of the socialization areas and citizenship relations, the importance of the identity is emphasized. Process of identity formation also includes choices of individuals in the issues of such as occupation, religious belief, political view, description of relational role. Social situations of the individuals and their roles in various groups in which they are members of them not only affect their identities (Hortacsu, 2007; 21) but also determine with which characteristics of them they are integrated in social life (Crocetti, Jahromi \& Meeus, 2012 ). Adolescence period is a critical period in which people decide how a person they will become and they make effort for the person they would like to be. In this sense, adolescence period has a special importance for providing young people to improve an identity having democratic values in democratic societies (Schmid, 2012).

In a study in which examples chosen by students in primary and secondary school about democratic behaviour in Kahramanmaras are examined, it has been stated that most of the students have exemplified elections of student council presidency at their schools (Bal \& Yigittir, 2013). And in another study done with $11^{\text {th }}$ grade students in Diyarbakir, it has been stated that student council studies increase decision making skills of the students, enable them to learn their rights and contribute to understanding of importance of electing and being elected (Gomleksiz and Curo, 2011).

It has been stated that being supported and liked by teachers who have been appreciated by them, which means being recognized as another person from his parents in adolescence period is very important for young individual and teachers are usually perceived as an oppressive enemies or experienced, sophisticated, thoughtful, mature role models or friend, sister and brother by students (Yorukoglu, 1993). In this sense, teachers and administrators who have role model characteristics have tremendous responsibilities in creating democratic life culture, one of the important ways of realizing democratization process is also adopting democratic life at school.

\section{Conclusions And Recommendations}

The fact that president of school council is a social person, has the ability of representation, physical characteristics of them are considered to be important in the result of the research and significant differences have also been stated in the issue of willing to be president of the school. These findings show parallelism with development characteristics of the period in which individuals who are participants of the research live. It has been understood that young people give words that they can't realize, they give tangible promises in candidate processes of school council presidency and students prefer that candidates must be older students. The fact that $75 \%$ of the students think that voting in elections of presidency of school council is a responsibility and 53\% of them also think that elections are realized in a just and democratic environment has been interpreted as most of the young people live democratic values and they pay attention to participation rights. The issues of the fact that candidates give tangible promises to the students and these promises aren't limited in this candidacy process have been criticized. Before questionnaire forms have been filled in the scope of the research, a substantial part of the students of Vocational and Technical Anatolian High school have expressed that they don't know system of school council presidency and their own president of the school and they haven't voted in the elections in explanation part for the students. The fact that Vocational and Technical Anatolian High school students gain democratic life style in high school years is very important has been assessed. To create a democratic atmosphere at school;

- It must be provided that democracy courses are not taught only theoretically, providing democratic values to adopt in school culture starting from child rights, 
- conducting information studies about the school in order to provide integration of the child on the first day of school and including participation right of the child in these studies absolutely,

- It must be provided that both administrators and teachers are role models for the students in acquisition of democratic value and behaviour starting from preschool period,

- Adoption of a democratic manner of rule due to the fact that quality of relationship between administrator and teacher at schools also determines relationship between teacher-student,

- It must be provided that students are given responsibilities that they can contribute to school process except homework at schools, these responsibilities don't just consist of understanding and working an issue and initiatives of the children are supported and teachers are only counsellors,

- Importance and aim of the elections of school council presidency must be explained to the students,

- It must be provided that elections of school council presidency include democratic elements completely

\section{References}

Ahmad, I., Said, H. \& Jusoh, A. (2015). Empirical Evidence on the Relationship Between Democratic Classroom and Social Skills Development of Students. Mediterranen Journal Of SocialSciences, 6 (2), 18-27. Doi: 10.5901/mjss.2015.v6n2s1p18.

Akbari, H. (2008). Educating Business Professionals For Year 2010 And Beyond: Six Critical Management Themes And Skills To Emphasize. International Business \& Eeconomics Research Journal, 7 (7), 57-62

Akdu, O. (2016). Ortaokul 8. Simf Vatandaşlık Ve Demokrasi Egitimi Dersinin Demokrasi Kulturune Katkısımm Ogrenci Goruslerine Gore Degerlendirilmesi: Burdur Ili Ornegi. （Yayımlanmamış Yuksek Lisans Tezi). Mehmet Akif Ersoy Universitesi/ Egitim Bilimleri Enstitusu, Burdur.

Akgun, I.H. (2013). Sekizinci Smaf Vatandaşllk ve Demokrasi Eğitimi Dersinde Ornek Olay Yontemiyle Oğretimin Oğrenme Duzeyine ve Kaluclĭga Etkisi. (Yayımlanmamış Doktora Tezi). Firat Universitesi/ Egitim Bilimleri Enstitusu, Elazıg.

Bal, S. \& Yigittir, S. (2013). Ilköğretim Ve Ortaöğretim Oğrencilerinin Demokrasi Algılarının Incelenmesi. Adiyaman Universitesi Sosyal Bilimler Enstitusu Dergisi Sosyal Bilgiler Oğretimi Ozel Sayzsi, 6 (14), 195-220.

Bee, H. \& Boyd, D. (2009). Çocuk Gelişim Psikolojisi. Okan Gündüz (Çev.). İstanbul: Kaknüs Yayınları.

Bessell, S. (2009). "Children's Participation in Decision-Making in The Philippines Understanding The Attitudes of Policy-Makers and Service Providers". Childhood, 16 (3); 299-316. doi: 10.1177/0907568209335305

Blair, H. (2003). Jump - Starting Democracy: Adult Civic Educationand Democratic Participation in Three Countries. Democratization, 10 (1), $53-76$.

Buyuksahin Cevik, G. \& Atıcı, M. (2008). Lise 3. Sınıf Öğrencilerinin Arkadaşlık İlişkilerinin Bazı Değişkenlere Göre İncelenmesi. C.Ü. Sosyal Bilimler Enstitüsü Dergisi, 17 ( 2), 35-50.

Cicognani, E.,Zani, B., Fournier, B., Gavray, C. \& Born, M. (2012). Gender Differences in Youths' Political Engagement and Participation. The Role of Parentsand of Adolescents' Socialand Civic Participation. Journal of Adolescence, 35, 561-576. Doi: 10.1016/j.adolescence.2011.10.002.

Cifci, İ. \& Sucuoglu, B. (2009). Bilişsel Süreç Yaklaşımıyla Sosyal Beceri Öğretimi. Ankara: Kök Yayıncillk. 
Sacan, S. (2017). How Do High School Students Elect Their President Of The School?Journal of Human Sciences, 14(2), 1338-1355. doi:10.14687/jhs.v14i1.NNNN

Crocetti, E., Jahromi, P. \& Meeus, W. (2012). Identity and civic engagement in adolescence. Journal of Adolescence, 35, 521-532 doi:10.1016/j.adolescence.2011.08.003.

Celiktas, S. (2009). Ortaögretim Ogrencilerinin Etkili Okul Oğrenci Meclisi Algzlarn (Bakurkoy I İcesi Orneği). (Yayınlanmamıs Yuksek Lisans Tezi). Beykent Üniversitesi/Sosyal Bilimler Enstitusu, İstanbul.

Davis, O. L. (2003). Editorial does democracy in education still live. Journal of Curriculum an Supervision, 19 (1), 1 - 4.

Derman, O. (2008). Ergenlerde Psikososyal Gelişim. İ.Ü. Cerrahpaşa Tip Fakültesi Sürekli Tip Eğitimi Etkinlikleri Adolesan Sağllğ1 II Sempozyum Dizisi No: 63, 19-21.

Dijkstra, J. K.,Kretschmer, T., Lindenberg, S. \& Veenstra, R. (2015). Hedonic, Instrumental,

And Normative Motives: Differentiating Patterns for Popular, Accepted, and Rejected Adolescents. Journal of Early Adolescence, 35(3) 308 - 328. doi: 10.1177/0272431614535092.

Ekici, O. (2013). Avusturya Ve Turkiye'deki Ortaokullarda Demokrasi Eğitimi Icerigine Ilişkin Oğretmen Goruslerinin Karsilaştırlması (Viyana-Diyarbakır Ornegi). (Yayınlanmamıs Yuksek Lisans Tezi). İnonu Universitesi/Egitim Bilimleri Enstitusu, Malatya.

Eurydice (2005) "Citizenship Education at School in Europe", http:// www.eurydice.org Erisim Tarihi: 20 Ocak 2016.

Gomleksiz, M. N. \& Curo, E. (2011). Demokratik Yurttaşlık Eğitimi Bağlamında Okul Öğrenci Meclisleri. Cukurova Üniversitesi Eğitim Fakültesi Dergisi, 1(40), 61-79.

Hortacsu, N. (2007). Ben Siz Biz Hepimiz: Toplumsal Kimlik ve Gruplararası İlişkiler. Ankara: İmge Kitabevi.

Kagıtcıbası, Ç. (2006). Yeni İnsan ve İnsanlar (10. Bask1). İstanbul: Evrim Yayınları.

Kıncal, R. Y. (2007). Vatandaşlık Bilgisi. (2. Baskı). Ankara: Nobel Yayın Dağıtım.

Koknel, O. (2011). Ergenlik Dönemi. Haluk Yavuzer (Ed.), Ana- Baba Okulu içinde (s.177- 217). Istanbul: Remzi Kitabevi.

Konak, A. (2012). Ilk:ögretim 6. Sinff Görsel Sanatlar Eğitimi Ders İci Etkinliklerinin Öğrencilerin Demokratik Tutumlarna Etkisi. (Yayımlanmamış Doktora Tezi). Marmara Üniversitesi/Ĕ̈itim Bilimleri Enstitüsü, İstanbul.

Korkmaz, M., Celebi, N., Yucel, A. S., Sahbudak, E., Karta, N. \& Sen, E. (2015). Eğitim Kurumlarında Yönetim ve Liderlik. Ankara: Nobel Akademik Yayıncilık.

Kulaksızoglu, A. (2006). Ergenlik Psikolojisi (8. Baskı). İstanbul: Remzi Kitabevi.

Kurtbas, I. (2016). Temsil Krizinin Aşılması Ve Demokrasinin Pekişmesi Bağlamında [Bağımsız] Aday Odaklı Bir Politik Sistem Önerisi. Kafkas Üniversitesi Sosyal Bilimler Enstitüsü Dergisi, 18, 421-445. Doi:10.9775/kausbed.2016.022.

Liu, J. H. \& Hilton, D. J. (2005). How the Past Weighs on thePresent: Socail Representations of History and Their Role in Identy Politics. British Journal of Social Psychology, 44, 537-556. Doi: 10.1348/014466605X27162.

Mager, U. \& Nowak, P. (2012). Effects Of Student Participation in Decision Making At School. A Systematic Review And Synthesis Of Empirical Research. Educational Research Review, 7 (1), 38-61.doi:10.1016/j.edurev.2011.11.001.

Milli Egitim Bakanlı1 10. Dönem Öğrenci Meclisi Çalışmaları (2013). http://ttkb.meb.gov.tr/www/demokrasi-egitimi-ve-okul-meclisleri-projesi/icerik/235. Erişim tarihi: 12.01.2016.

Milli Egitim Bakanlig1 2010-2014 Stratejik Plan1.

http://sgb.meb.gov.tr/Str_yon_planlama_V2/MEBStratejikPlan.pdf Erişim Tarihi: 19.01.2016.

Milli Egitim Bakanlı1 2015-2019 Stratejik Plan1.

http://sgb.meb.gov.tr/meb_iys_dosyalar/2015_09/10052958_10.09.2015sp17.15imzasz. pdf Erişim Tarihi: 19.01.2016.

Mueller, D. C. (2009). Reason, Religion and Democracy. UK: Cambridge University Press.

Nacak, O. (2015).Türk Yönetim Anlayışında Bir Değişim: Siyasal Temsilin Doğuşu ve Gelisimi. Afyon Kocatepe Üniversitesi Sosyal Bilimler Dergisi, 17 (1), 147-169.Doi: 10.5578/JSS.8765. 
Pamuk, I. \& Pamuk, A. (2016). Almanya'da Sachunterricht ve Türkiye'de Hayat Bilgisi Ders Kitaplarında Okulda Demokrasi Uygulamalarına Örnek Olarak Sınıf Başkanı Seçimi. Cumburiyet International Journal of Education-CIJE, 5 (2), 67-83.

Schmid, C. (2012). The Value "Social Responsibility" As A Motivating Factor For Adolescents' Readiness To Participate In Different Types Of Political Actions, And Its Socialization In Parent And Peer Contexts. Journal of Adolescence, 35, 533-547 doi:10.1016/j.adolescence.2012.03.009.

Stephenson, P., Gourley, S. \& Miles, G. (2004). Child Participation. Blackman, R. (Ed.) Teddington, United Kingdom: Tearfund.

Subaşı, G. (2009). Ergenlerde Sosyometrik Statü Gruplarına Göre Sosyal Kayg1 Farklılıkları ve Akran İlişkileri. Ege Ë̈itim Dergisi, 10 (1), 114-1361.

TBMM Kültür Sanat ve Yayın Kurulu Baskanllg1 (2015). Türkiye Oğrenci Meclisi Demokrasi Egitimi Ve Okul Meclisleri. Erişim Tarihi: 12.11.2015.https://www.tbmm.gov.tr/kultursanat/tom_hakkinda.htm.

Thornberg, R. (2010). School Democratic Meetings: Pupil Control Discourse In Disguise. Teaching and Teacher Education, 26 (4), 924-932. doi:10.1016/j.tate.2009.10.033.

Thornberg, R. \& Elvstrand, H. (2012). Children's Experiences Of Democracy, Participation, And Trust in School. International Journal of Educational Research, 53, 44-54. doi:10.1016/j.ijer.2011.12.010.

Tezcan, M. (2015). Gençlik Kültür ve Toplum. Ankara: Anı Yayıncllık.

Toktok, N. (2010).Türkiye'de Demokrasi Kültürü. Turan Stratejike, Arasttrmalar Merkę̧i Dergisi, 2 (7), 135-142.

Tuzun, I. ve Sarısık, Y. (2015). Turkiye'de Okullarda Çocuk Katılımı: Durum Analizi. İstanbul: Istanbul Bilgi Universitesi Yayınları: 497.

Ulusal Çocuk Hakları Strateji Belgesi ve Eylem Planı (2013-2017). Erişim Tarihi: 01.01.2016. http://www.kdkcocuk.gov.tr/contents/files/YasalDuzenlemeler/Ulusal cocuk_Haklari Strateji Belgesi ve Eylem Plani.pdf.

Yesilorman, M. (2010). Siyasal Sosyalizasyon Surecinde Sosyo-Ekonomik Faktorlerin Rolu. Bilig, 36, 1-46.

Yıldız-Baklavacı, G. (2015). Ortaokul Öğrencilerinin Okul Öğrenci Meclislerine İlişkin Tutumlar.(Yayımlanmamis Yuksek Lisans Tezi). Marmara Universitesi/Egitim Bilimleri Enstitusu, İstanbul.

Yigit, M. F. (2014). Cok Kulturlu Toplumlarda Deger Yarglar, Vatandaşlık Ve Demokrasi Egitimi: Turkiye Ornegi. (Yayımlanmamış Doktora Tezi). Necmettin Erbakan Universitesi/Egitim Bilimleri Enstitusu, Konya.

Yorukoglu, A. (1993). Genclik Cağı (8. Baskı). İstanbul: Ozgur Yayın Dagıtım. 